\title{
System pomocy społecznej a starzenie się populacji - wyzwania i bariery w zakresie opieki długoterminowej
}

\begin{abstract}
Streszczenie
Starzenie się populacji Polski stawia przed społeczeństwem wyzwania związane z koniecznością zabezpieczenia zróżnicowanych potrzeb rosnącej grupy osób starszych. Pomimo postępu cywilizacyjnego (m.in. w zakresie technologii medycznych) nie każda osoba starsza będzie się cieszyła dobrym zdrowiem i zachowa zdolność do samoopieki do ostatnich dni życia. Część seniorów będzie mogła w przypadku wystąpienia różnego typu ryzyka, m.in. socjalnego lub zdrowotnego, liczyć na wsparcie ze strony rodziny. Natomiast według prognoz demograficznych i ekonomicznych zwiększać się będzie liczba seniorów, których zabezpieczenie potrzeb będzie uzależnione od wsparcia ze strony sektora pomocy społecznej. Celem artykułu jest przedstawienie, przed jakimi wyzwaniami staje sektor pomocy społecznej w związku z procesem starzenia się populacji. W szczególności, jakie są zakres, formy i rodzaje świadczeń z pomocy społecznej dla osób starszych oraz jakie są główne ograniczenia i bariery w ich realizacji. Zaprezentowane dane wskazują, że rządzącym w Polsce trudno będzie w najbliższym czasie sprostać zapotrzebowaniu na usługi opiekuńcze, szczególnie w wymiarze długoterminowym z uwagi na niedostatek zasobów, w tym ludzkich, finansowych itp. Dodatkowo w agendzie politycznej nie widać nacisku na tę sferę polityki publicznej.
\end{abstract}

Słowa kluczowe: opieka długoterminowa, pomoc społeczna, starzenie

\section{Social welfare system and ageing population - challenges and barriers in long-term care}

\begin{abstract}
The ageing of Polish population poses a challenge to the society resulting in the necessity to meet the needs of the increasing number of the elderly. Despite the progress of
\end{abstract}

1 Uniwersytet Szczeciński, Katedra Pedagogiki Społecznej 
civilization (i.a. in medical technology), not every elderly person will be in good health and maintain their ability to care for themselves until their last days. In the event of some kinds of risks, i.a. social or health, some seniors will be able to count on their families' support, whereas the number of seniors who are dependable on social welfare institutions will continue to increase, according to the latest demographic and economic forecasts. The aim of this article is to present the challenges the social welfare system has to face as a result of the ageing population. In particular, the coverage, forms and kinds of benefits the elderly receive from the social welfare, and what main limits and barriers they have to overcome to receive them. The presented data suggests that the government will experience difficulties with meeting the demands for care services, especially long-term ones, due to the lack of resources, including human and financial ones. In addition, the policy agenda does not show any form of pressure on this area of public policy.

Keywords: long-term care, social welfare, ageing

Sektor pomocy społecznej jest niezwykle istotnym elementem systemu opieki nad niesamodzielni osobami starszymi, obok instytucji sektora ochrony zdrowia oraz rodzin. Instytucje pomocy społecznej obejmują potrzebującego seniora całodobową, kompleksową opieką, ale również wspierają rodziny w czynnościach pielęgnacyjnych nad osobą starszą, np. w formie środowiskowej czy też dziennych domach pomocy społecznej. Celem artykułu jest przedstawienie wybranych kategorii barier stojących przed instytucjami pomocy społecznej, których zadaniem jest udzielanie wsparcia w codziennym funkcjonowaniu niesamodzielnym seniorom, w perspektywie starzenia się społeczeństwa. Analiza zagrożeń i wyzwań, które stoją przed pomocą społeczną w zakresie pomocy osobom starszym przeprowadzona została na podstawie danych statystycznych i finansowych Ministerstwa Rodziny, Pracy i Polityki Społecznej, aktów prawnych regulujących działalność tego sektora oraz badań własnych autora przeprowadzonych w instytucjach i rodzinach, które udzielają wsparcia niesamodzielnym seniorom. Badania prowadzone były w $2014 \mathrm{r}$. na terenie województwa zachodniopomorskiego. Przeprowadzono wywiady pogłębione z osobami odpowiedzialnymi za kreowanie i wdrażanie rozwiązań z zakresu opieki długoterminowej w województwie zachodniopomorskim oraz opiekunami profesjonalnymi i rodzinnymi niesamodzielnych osób starszych. W najbliższym czasie rządzącym w Polsce trudno będzie sprostać zapotrzebowaniu na usługi opiekuńcze, szczególnie w wymiarze długoterminowym z uwagi na niedostatek zasobów, w tym ludzkich, finansowych itp. Dodatkowo w agendzie politycznej nie widać nacisku na tę sferę polityki publicznej. 


\section{Starzenie się populacji}

Dane demograficzne wskazują na rosnący udział osób starszych w populacji Polski. W 2016 r. 16,4 proc. mieszkańców kraju miało 65 i więcej lat. We wspomnianym roku mediana wieku wynosiła 38,6 lat dla mężczyzn i 41,9 lat dla kobiet (GUS, 2018). Według prognoz demograficznych w 2070 r. udział osób starszych w populacji przekroczy poziom 33,3 proc., a mediana wieku będzie się zbliżać do 50 lat (EC, 2018). Polska jest zaliczana do grona państw, w których proces starzenia się populacji przybierze wyraźnie gwałtowny wymiar. Jeśli obecne trendy demograficzne się utrzymają, staniemy się jedną z najstarszych populacji spośród krajów Unii Europejskiej (rysunek 1).

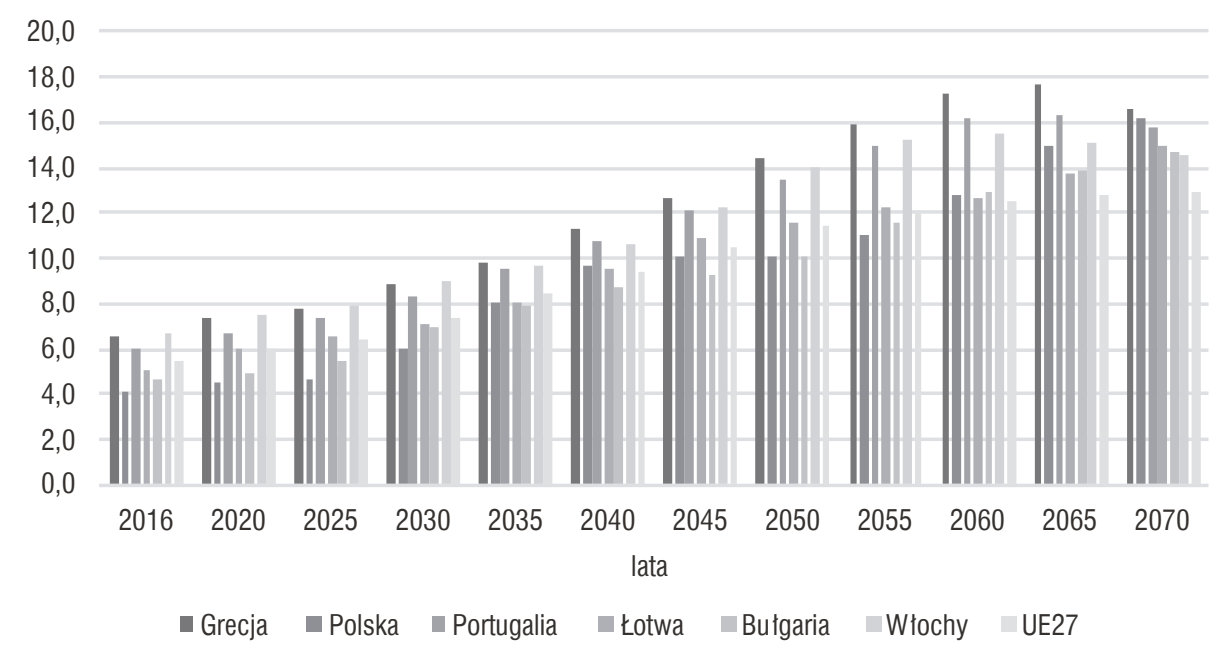

Rysunek 1. Osoby w wieku 80 i więcej lat jako proc. populacji w wybranych krajach UE w latach 2016-2070

Źródło: The 2018 Ageing Report Economic \& Budgetary Projections for the 28 EU Member States (2016-2070).

W 2016 r. w krajach zrzeszonych w UE osoby powyżej 80. roku życia stanowiły 5,5 proc. populacji, do 2070 r. ich udział wzrośnie do niemal 13 proc. Polska zalicza się do grona państw, w przypadku których odsetek osób osiągających ósmą dekadę życia przekroczy średnią dla krajów UE i wyniesie aż 16,2 proc., wyższy prognozowany jest jedynie w Grecji (16,6 proc.). Polska odnotuje równie największy wzrost ich liczby - o 12 proc. w analizowanym okresie (EC, 2018). Są to szczególnie istotne dane, ponieważ wraz z wiekiem rośnie ryzyko wystąpienia niesamodzielności. 
Przyjęło się uznawać osoby za starsze na podstawie ich wieku kalendarzowego, a przecież starość jest procesem wybitnie zróżnicowanym, który możemy rozpatrywać m.in. na płaszczyźnie: ekonomicznej, psychologicznej, socjologicznej, prawno-socjalnej i biologicznej. Starzenie jest procesem o charakterze indywidualnym, ponadto okres starości możemy podzielić na kilka etapów, które mają wyraźny wpływ na szanse występowania poszczególnych rodzajów ryzyka (np. zdrowotnego, socjalnego), ale również warunkują wymiar potrzeb, które osoba starsza powinna zaspokoić, aby możliwe było utrzymanie odpowiedniego poziomu komfortu i jakości życia.

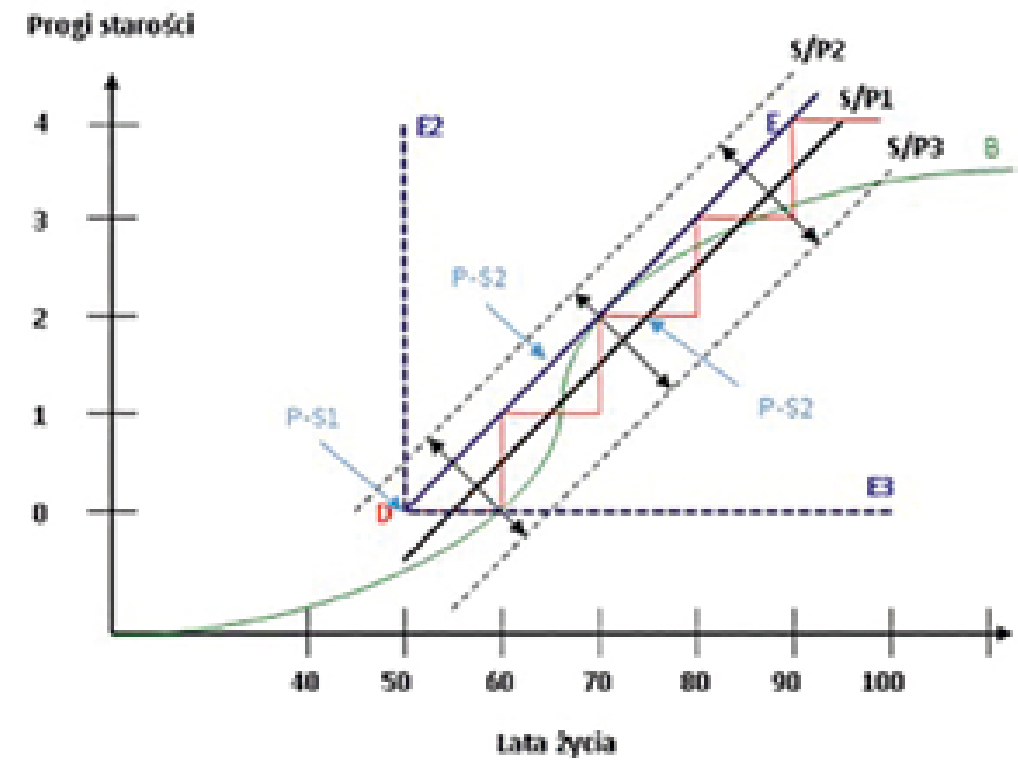

\section{Rysunek 2. Progi starości}

D - demograficzne progi starości

E - ekonomiczne progi starości

S/P - społeczno-psychologiczne progi starości

B - biologiczne progi starości

P-S - prawno-socjalne progi starości

Źródło: Iwański (2017: 116).

Starzenie jest wypadkową wielu zmiennych, które mają zróżnicowane znaczenie dla poszczególnych osób (rysunek 2). Dla części populacji dominujące będą kwestie związane z biologicznym procesem starzenia się organizmu, dla innych pełnione role rodzinne czy też zawodowe. Należy jednak zdecydowanie podkreślić, że potrzeby osoby wkraczającej w pierwszy etap starości, czyli po przekroczeniu 65. roku życia, są zdecydowanie inne niż seniora, który osiągnął wiek 85-90 lat, czyli wkracza w tzw. okres starości sędziwej. Ponadto wraz z wiekiem zmienia się nie tylko tzw. koszyk potrzeb, 
ale również możliwość ich zaspokajania przy wykorzystaniu zasobów własnych, rodziny oraz środowiska lokalnego. Należy mieć na uwadze, że w najbliższych latach wzrastać będzie odsetek jednoosobowych gospodarstw domowych, prowadzonych przez samotne osoby starsze. Już w 2017 r. w gospodarstwach, w których mieszkały wyłącznie osoby w wieku 60 i więcej lat przeważały jedno i dwuosobowe gospodarstwa domowe (GUS, 2018b).

Przed starzejącymi się społeczeństwami stoi wiele wyzwań i kwestii, które związane są z koniecznością zabezpieczenia potrzeb rosnącej liczby osób starszych przy jednoczesnym zmniejszaniu się liczebności osób w wieku produkcyjnym. Jako społeczeństwo stajemy przed wyzwaniem, jak zwiększyć wydajność naszej gospodarki przy zmniejszających się dostępnych zasobach na rynku pracy, z równoczesnym prognozowanym wzrostem nakładów na politykę społeczną ukierunkowaną na zaspokajanie potrzeb seniorów. W przypadku opieki długoterminowej nad niesamodzielnymi osobami starszymi zauważalna jest duża aktywność w zakresie tworzenia wytycznych, planów oraz polityki związanych z tą sferą, lecz nie przekłada się to na wyraźną, rzeczywistą poprawę systemu opieki (Bakalarczyk, 2017). Sama polityka społeczna skierowana na zaspokajanie zróżnicowanych potrzeb rosnącej populacji osób starszych ma niekiedy wymiar incydentalny, krótkoterminowy. Podejmowane inicjatywy nie są projektowane i planowane w ujęciu perspektywicznym, długoterminowym, lecz wydają się być zależne od tzw. kalendarza politycznego (Szatur-Jaworska, 2015).

\section{Opieka długoterminowa nad osobami starszymi}

Wraz z wiekiem wzrasta ryzyko wystąpienia niesamodzielności. Niekiedy jest to skutkiem naturalnego procesu starzenia się organizmu, ale zdecydowanie częściej wynikiem chorób lub urazów. Rosnące zapotrzebowanie na usługi opiekuńcze świadczone na rzecz niesamodzielnych osób starszych stanie się jednym z głównych wyzwań, przed jakim stanie pomoc społeczna w najbliższych latach. Według obecnie obowiązujących przepisów, za organizację i współfinansowanie świadczeń opiekuńczych odpowiedzialne są w Polsce głównie władze samorządowe - gminy. Pomoc osobom starszym świadczona może być m.in. w następujących formach i instytucjach:

- w domach pomocy społecznej,

- w rodzinnych domach pomocy społecznej,

- w dziennych domach pomocy społecznej,

- w mieszkaniach chronionych i wspomaganych,

- w formie świadczeń środowiskowych. 
Poszczególne gminy w Polsce prowadzą zróżnicowaną politykę w zakresie zabezpieczania potrzeb opiekuńczych osób starszych. Część samorządów stara się wykorzystać wszystkie dostępne i przewidziane prawem formy wsparcia, aby w jak największym stopniu zaspokoić potrzeby opiekuńcze swoich mieszkańców. Są również samorządy, na terenie których nie uświadczy się żadnej z wymienionych form wsparcia (NIK, 2018). Przyczyn tak znaczących różnic można upatrywać w dwóch podstawowych czynnikach: braku świadomości oraz braku środków finansowych. Niezależnie od przyjętej formy wsparcia, choć ustawodawca zakłada współfinansowanie świadczeń przez świadczeniobiorców i osoby zobowiązane do alimentacji, finalnie zdecydowaną większość kosztów ponoszą samorządy.

\section{Domy pomocy społecznej}

Jednym z głównych typów instytucji pomocy społecznej nastawionych na zaspokajanie potrzeb opiekuńczych osób niesamodzielnych są domy pomocy społecznej (DPS). Pod koniec 2017 r. w Polsce zarejestrowanych było 598 placówek, prowadzonych przez władze samorządowe lub organizacje pozarządowe. W DPS-ach przebywało w analizowanym roku 78896 osób, a zdecydowaną większość mieszkańców stanowiły osoby w wieku 60 i więcej lat (MRPiPS-05, 2018).

Obecnie w polityce społecznej państwa oraz wielu samorządów niezwykle istotna jest koncepcja dezinstytucjonalizacji opieki długoterminowej, czyli odchodzenie od opieki w formie stacjonarnej na rzecz świadczeń realizowanych w środowisku, w tym w mieszkaniach chronionych i wspomaganych (Krzyszkowski, 2018). Sama idea jest warta uwagi, lecz wydaje się, że dla wielu samorządów stanowi argument przeciw inwestycjom w budowę nowych domów pomocy społecznej. Niezależnie od przyjętego modelu zawsze będzie istniało zapotrzebowanie na świadczenia opiekuńcze realizowane w formie stacjonarnej. Od 2013 do 2018 r. zasoby pomocy społecznej w zakresie miejsc w domach pomocy społecznej wzrosły zaledwie o 1455 miejsc (MRPiPS-03-R, za lata 2013-2017).

W pierwszej kolejności należy mieć na uwadze, że z każdym rokiem rośnie odsetek mieszkańców DPS, którzy ze względu na stan zdrowia nie opuszczają łóżek. W 2016 r. w skali kraju w domach pomocy społecznej mieszkało prawie 10 tys. osób, które stale przebywały w łóżkach, co stanowiło 13 proc. mieszkańców placówek (MPiPS-3, 2017). W najbliższych latach w związku z procesem starzenia się populacji będzie wzrastała liczba osób, które wymagać będą całodobowej opieki. Opieka $\mathrm{w}$ formie środowiskowej, aby była właściwa względem potrzeb oraz bezpieczna dla seniora, wymaga zaangażowania odpowiednich sił i środków. W przypadku osób, 
które przejawiają niską zdolność do samoopieki, opiekę świadczyć musi rodzina, wspierana ewentualnie przez zawodowych opiekunów lub przedstawicieli zawodów medycznych (pielęgniarki opieki długoterminowej, pielęgniarki środowiskowe, opiekunów medycznych). Warto podkreślić, że bez filaru w postaci rodziny opieka nad osobą całkowicie niesamodzielną realizowana $\mathrm{w}$ formie środowiskowej nie jest w stanie zaspokoić podstawowych potrzeb seniora ze względu na ograniczenia czasowe i organizacyjne opieki publicznej. Wymiar czasowy przyznanych świadczeń opiekuńczych przez ośrodki pomocy społecznych wynosi najczęściej do 2 do 4 godzin dziennie. W przypadku gdy rodzina nie jest w stanie zapewnić bezpiecznej i właściwej do potrzeb opieki, lub nie chce tego robić, alternatywę stanowią placówki stacjonarne opiekuńcze, w tym mieszkania chronione lub wspomagane. W przypadku zamożniejszych gospodarstw można skorzystać $\mathrm{z}$ domów opieki, osobom bez odpowiednich zasobów finansowych pozostają publiczne domy pomocy społecznej.

Wiele domów pomocy społecznej zostało utworzonych w budynkach, które były adaptowane do celów opiekuńczych. Autor artykułu w 2014 r. prowadził badania na terenie województwa zachodniopomorskiego, których jednym z elementów były wizyty w placówkach, w których przebywają osoby starsze, i ocena pod kątem stanu obiektów, ich funkcjonalności i występujących barier architektonicznych ${ }^{2}$.

Część placówek utworzono w budynkach objętych ochroną konserwatora zabytków, co uniemożliwia lub znacząco utrudnia przeprowadzenie modernizacji i remontów. Niewątpliwą zaletą takich lokalizacji są parki, które przynależą do obiektu i tzw. walory środowiskowe. Niestety, układ pomieszczeń, ciągów komunikacyjnych nie jest przystosowany do potrzeb osób o ograniczonej samodzielności. Jednym z głównych mankamentów jest brak łazienek w pokojach. Niedogodności mają ogromne znaczenie dla opiekunów, których praca w takich warunkach jest utrudniona (Iwański, 2016).

Warto podkreślić, że od wielu lat trwa proces standaryzacji, który wymusza dokonywanie modernizacji w celu uzyskania optymalnych warunków dla życia seniorów i pracy opiekunów, pielęgniarek itd. W najbliższych latach można się spodziewać, że część domów trzeba będzie zamknąć ze względu na brak możliwości spełnienia rosnących wymogów, m.in. sanitarnych, przeciwpożarowych oraz ergonomii stanowisk pracy opiekunów. Jeśli nie zostaną podjęte inicjatywy w zakresie rozbudowy lub chociaż odtworzenia obecnych zasobów (modernizacje, rozbudowa itd.), to w kolejnych latach możemy spodziewać się wydłużenia kolejek osób oczekujących na przyjęcie do domów pomocy społecznej.

2 Szczegółowy raport z badań został zawarty w publikacji: R. Iwański, Opieka długoterminowa nad osobami starszymi, CeDeWu, Warszawa 2016. 
Kolejnym niezwykle istotnym zagadaniem jest kadra pracująca w domach pomocy społecznej. W tego typu placówkach pracuje ponad 55 tys. osób (MRPiPS, 2018). W wielu rejonach kraju zarobki pracowników działów terapeutyczno-opiekuńczych, które stanowią filar placówek, oscylują wokół najniższej płacy krajowej. Często spotykanym zjawiskiem jest nawet wliczanie dodatku wynikającego $\mathrm{z}$ wysługi lat do podstawy wynagrodzenia. W przypadku mniejszych miejscowości dom pomocy społecznej jest często największym pracodawcą, który gwarantuje niskie, ale stabilne dochody. Natomiast w przypadku dużych miast zauważalne są w wielu placówkach niedobory kadrowe i duża rotacja pracowników.

Warto podkreślić, że ustanowione prawnie zasady określające, ilu pracowników powinno pracować w DPS w przeliczeniu na jednego mieszkańca, nie są doskonałe. W domach dla osób w podeszłym wieku na jednego mieszkańca powinno przypadać 0,4 opiekuna, w pozostałych typach domów (dla osób przewlekle somatycznie chorych, osób przewlekle psychicznie chorych, osób dorosłych niepełnosprawnych intelektualnie, osób niepełnosprawnych fizycznie, osób uzależnionych od alkoholu) nie mniej niż 0,5 opiekuna na mieszkańca (Dz. U. 2018, poz. 734). Rozporządzenie dookreśla, że liczba opiekunów może uwzględniać wolontariuszy, stażystów i praktykantów (ale ich udział nie może przekroczyć 10 proc. pracowników działów terapeutyczno-opiekuńczych). Przyjęte kryteria uwzględniają liczbę osób, które mają etat opiekuna, ale nie zawsze muszą wykonywać pracę bezpośrednio na rzecz seniorów. W niektórych placówkach etaty opiekuńcze mają kierowcy, pracownicy gospodarczy, kapelani. Wykazywani są w sprawozdaniach i podczas kontroli przeprowadzanych przez poszczególne urzędy wojewódzkie, ale często ich faktyczne obowiązki (również ważne z punktu widzenia placówki) nie są związane z czynnościami opiekuńczymi. Należy dodatkowo pokreślić, że choć w domach pomocy społecznej przebywa coraz więcej osób o niskim stopniu samodzielności, to zmniejsza się liczba pracujących tam pielęgniarek. Jest to problem, który dotyczy również podmiotów ochrony zdrowia, lecz w przypadku DPS już dziś brakuje pielęgniarek, a za kilka lat może ich kompletnie zabraknąć. Domy pomocy społecznej nie są atrakcyjnym miejscem pracy dla pielęgniarek. Podczas prowadzenia badań w 2014 r. okazało się, że w zachodniopomorskich domach pomocy społecznej zdecydowana większość zatrudnionych pielęgniarek miała około 50 lat. W placówkach zatrudniani są opiekunowie medyczni, ale zakres ich uprawnień jest mniejszy niż pielęgniarek, które są niezbędne do zapewnienia seniorom właściwej opieki.

Niezwykle istotną kwestią w kontekście funkcjonowania domów pomocy społecznej są również problemy związane z finansowaniem świadczeń opiekuńczych. Według ustawy o pomocy społecznej (2004) w pierwszej kolejności opłatę za pobyt w DPS wnosi sam senior, ale do wysokości maksymalnie 70 proc. świadczenia emerytalnego, 
rentowego lub socjalnego. Jeśli odprowadzona kwota jest niewystarczająca na pokrycie kosztów pobytu, w drugiej kolejności opłatę wnoszą członkowie rodziny zobowiązani do alimentacji. Dopiero na końcu brakująca kwota uzupełniana jest ze środków budżetów władz samorządowych lub w przypadku osób umieszczonych w DPS przed 2004 rokiem opłatę wnosi wojewoda.

Tabela 1. Dopłaty ze strony gminy do pobytu mieszkańców domów pomocy społecznej - stan na początek 2017 r.

\begin{tabular}{|l|c|c|c|}
\cline { 2 - 4 } \multicolumn{1}{c|}{} & DPS w Szczecinie & DPS poza powiatem & Razem \\
\hline Liczba osób umieszczonych w DPS & 597 & 299 & 896 \\
\hline $\begin{array}{l}\text { Liczba osób, za które gmina dopłaca } \\
\text { za pobyt w DPS }\end{array}$ & 562 & 292 & 854 \\
\hline $\begin{array}{l}\text { Udział osób, za które gmina dopłaca } \\
\text { za pobyt w DPS }\end{array}$ & 94,13 proc. & 97,65 proc. & 95,31 proc. \\
\hline Maksymalna dopłata ze strony gminy & 3705 PLN & 2950 PLN & 3328 PLN \\
\hline Średnia dopłata ze strony gminy & 1822 PLN & 1987 PLN & 1904 PLN \\
\hline
\end{tabular}

Źródło: Giezek i in. (2018).

W tabeli 1 przedstawione zostały dane dotyczące kosztów pobytu mieszkańców gminy Szczecin w domach pomocy społecznej. W 2016 r. 896 mieszkańców Szczecina przebywało w DPS, z czego tylko 4,69 proc. ponosiło koszty pobytu bez wsparcia gminy. Średnia dopłata do jednej osoby w skali roku, jaką wnosiła gmina, wyniosła 1904 PLN. W skali kraju osoby wnoszące opłatę za pobyt w DPS bez dopłaty ze strony gminy stanowią zaledwie 3,3 proc. ogółu mieszkańców ponadgminnych placówek opiekuńczych przyjętych po 2004 r. (MRPIS-03, 2017).

Dla wielu ośrodków pomocy społecznej, szczególnie z mniejszych miejscowości, $\mathrm{w}$ tym wiejskich, wniesienie opłaty za pobyt mieszkańca gminy w domu pomocy społecznej stanowi duże wyzwanie w wymiarze ekonomicznym. Budżety poszczególnych ośrodków nie są w stanie udźwignąć tak dużych kosztów długookresowych. Ponadto osoby z terenów wiejskich często mają niższe świadczenie emerytalne lub rentowe, a rodzina nie osiąga przewidzianego prawnie kryterium dochodowego, od którego obowiązuje alimentacja. Świadomość dużych obciążeń prowadzi do sytuacji, że pracownicy pomocy społecznej zmuszeni są odwlekać wydanie decyzji o skierowaniu do domów pomocy społecznej osoby, która spełnia (niezbyt wygórowane) przewidziane prawem kryteria ze względu na brak w budżecie ośrodka środków na pokrycie kosztów dopłat.

Podczas badań własnych autor artykułu w czasie rozmów z pracownikami domów pomocy społecznej spotykał się z opiniami, że do placówek niektóre gminy kierują osoby ze względów socjalnych, choćby $\mathrm{w}$ ramach walki $\mathrm{z}$ bezdomnością. Warto 
podkreślić, że od połowy 2018 r. obowiązuje rozporządzenie Ministra Rodziny, Pracy i Polityki Społecznej dotyczące m.in. schronisk dla osób bezdomnych z usługami opiekuńczymi (z dnia 14 maja 2018 r.), które umożliwia władzom samorządowym zabezpieczenie potrzeb opiekuńczych osób bezdomnych w nowym typie placówek.

Ponadto dyrektorzy domów pomocy społecznej skarżyli się niekiedy, że ośrodki nie chcą kierować do nich osób, które potrzebują całodobowej opieki lub zwlekają z przekazaniem dokumentów ze względu na oszczędności. Prowadzi to do sytuacji, gdy w danym rejonie jest zapotrzebowanie na świadczenia w zakresie opieki długoterminowej realizowanej w DPS, a $\mathrm{z}$ drugiej strony $\mathrm{w}$ domach są wolne miejsca. Zdecydowana większość kosztów funkcjonowania domów pomocy społecznej ma charakter stały, powstałe deficyty wynikające z niepełnego obłożenia zmuszają dyrektorów do szukania oszczędności, które mogą wpłynąć na jakość świadczonej opieki.

Domy pomocy społecznej są niezbędne w starzejącym się społeczeństwie, lecz należy rozważnie dysponować dostępnymi zasobami, tak aby do placówek trafiały osoby, które faktycznie nie są w stanie otrzymać właściwej opieki w środowisku. Ponadto konieczne jest dostosowanie warunków opiekuńczych do potrzeb osób o niskim stopniu samodzielności - leżących, których w najbliższych latach będzie przybywać. Opiekunowie, aby świadczyć pomoc, muszą mieć odpowiednio wyposażone i przygotowane stanowiska pracy, które będą bezpieczne zarówno dla seniorów, jak i dla nich samych. Dziś zauważalne są duże zaniedbania w tym zakresie, a jakość opieki i komfort osób mieszkających w domach pomocy społecznej w dużym stopniu uzależnione są od warunków pracy opiekunów. Część placówek nie było projektowanych i budowanych z przeznaczeniem dla tak dużej liczby osób, które nie opuszczają łóżek. W wielu domach pomocy społecznej brakuje łazienek indywidualnych dla poszczególnych pokoi. Często też mieszkańcy zmuszeni są mieszkać w pokojach wieloosobowych, co znacząco może obniżyć jakość pobytu w DPS.

\section{Mieszkania chronione i wspomagane}

W wielu miastach w Polsce podejmowane są inicjatywy związane z uruchomieniem mieszkań chronionych i wspomaganych dla osób starszych. Pierwszy typ lokali przeznaczony jest dla osób, które nie są zdolne do samodzielnej egzystencji i przejawiają znikomą zdolność do samoopieki i samopielęgnacji. Mieszkania chronione stanowią alternatywę dla domów pomocy społecznej. Po pierwsze, w lokalu mieszka średnio 5-6 seniorów, przez całą dobę w lokalu obecna jest przynajmniej jedna opiekunka. Mieszkania mogą być zlokalizowane w różnych częściach miasta, co pozwala na utrzymanie seniora w znanym otoczeniu, np. dzielnicy. Mieszkania 
chronione są w pełni przystosowane (sanitariaty, ciągi komunikacyjne, pokoje), aby możliwe było zapewnienie seniorom bezpiecznej i właściwej do potrzeb opieki. Koszt uruchomienia mieszkania, pod warunkiem, że gmina dysponuje wolnymi lokalami o odpowiednich parametrach ok. 100 mkw., w przypadku Szczecina kształtował się na poziomie od 54500 do 170731 PLN (Giezek, Iwański, 2017).

Mieszkania wspomagane są przeznaczone dla seniorów, którzy przejawiają zdolność do samodzielnej egzystencji, ewentualnie wymagają jedynie wsparcia udzielanego przez opiekunki środowiskowe. W Szczecinie w 2015 r. oddano do użytku 26 tego typu lokali, a w 2019 r. 19 kolejnych. Inwestycja została przeprowadzona przez Szczecińskie Towarzystwo Budownictwa Społecznego, a następnie lokale zostały oddane do dyspozycji Miejskiemu Ośrodkowi Pomocy Rodzinie w Szczecinie. MOPR przeprowadził nabór chętnych do lokali i sprawuje nad nimi pieczę. W procedurze konkursowej wybrane zostały osoby starsze, w przypadku których zachodziła pilna potrzeba zaspokojenia potrzeb mieszkaniowych. Lokale zostały zaprojektowane w taki sposób, aby umożliwić seniorom jak najdłuższą samodzielną egzystencję, nawet przy wystąpieniu ograniczeń charakterystycznych dla osób z tzw. sędziwej starości. Warto podkreślić, że lokale są zlokalizowane w bliskim sąsiedztwie klubu seniora.

\section{Opieka środowiskowa}

Według raportu Najwyższej Izby Kontroli (NIK, 2018), w co piątej gminie nie są świadczone usługi opiekuńcze na rzecz osób starszych w miejscu zamieszkania. Jest to najtańsza i skuteczna forma pomocy osobom niesamodzielnym oraz opiekunom rodzinnym. Problem ten częściej występuje w gminach o charakterze wiejskim, w których istotnym ograniczeniem jest duże rozproszenie potencjalnych świadczeniobiorców. Ponadto część kierowników ośrodków pomocy społecznej uważa, że to podmioty sektora ochrony zdrowia właściwe są do świadczenia usług opiekuńczych (Iwański, 2016). Ryzyko wystąpienia niesamodzielności dotyczy pewnej części populacji osób starszych, ale nie ma możliwości, aby na terenie 20 proc. gmin w Polsce nie było zapotrzebowania na tę formę świadczeń. Warto podkreślić, że na gminach ciąży ustawowy obowiązek organizacji usług opiekuńczych w formie środowiskowej, lecz niespełnienie tego wymogu nie przekłada się na znaczące dla władz samorządowych sankcje.

W przypadku opieki środowiskowej opiekunem może zostać osoba, która nie ma żadnych kwalifikacji w tym zakresie, jedynie w przypadku specjalistycznych usług opiekuńczych wymagane jest wykazanie przygotowania zawodowego. Ponieważ zarobki opiekunów środowiskowych są bardzo niskie, najczęściej tak jak w przypadku 
opiekunów w DPS kształtują się w okolicach najniższej płacy krajowej, zauważalna jest negatywna selekcja do zawodu. Jest to praca trudna, w zróżnicowanych środowiskach (np. osób starszych $\mathrm{z}$ chorobą alkoholową lub niezdiagnozowanymi i nieleczonymi zaburzeniami psychicznymi), której zakres obejmuje od podstawowych prac w gospodarstwie domowym (pranie, przygotowanie posiłku) po zabiegi pielęgnacyjne i higieniczne.

Opiekę środowiskową mogą świadczyć osoby zatrudnione w ośrodkach pomocy społecznej oraz pracownicy firm lub organizacji pozarządowych wyłonionych w przetargach na świadczenie usług. Coraz popularniejszym modelem staje się zlecanie czynności opiekuńczym firmom. Jednym z głównych argumentów przemawiających za zlecaniem usług opiekuńczych podmiotom spoza ośrodka pomocy społecznej jest obniżenie kosztów opieki. Według raportu NIK (2018) przeciętny roczny koszt wsparcia usługami opiekuńczymi jednej osoby starszej, w przypadku gdy świadczenia wykonuje osoba zatrudniona w ośrodku pomocy społecznej, wyniósł w $2016 \mathrm{r}$. 8626 PLN. Kiedy pomoc świadczona jest za pośrednictwem podmiotu zewnętrznego, przeciętny koszt wynosi 3892 PLN.

Choć prosty rachunek ekonomiczny powinien przemawiać na korzyść organizacji usług opartej na podmiotach zewnętrznych (firmy i organizacje pozarządowe), to należy mieć na uwadze również czynniki związane z kwestiami pracowniczymi i wymiarem usług. W pierwszej kolejności należy podkreślić, że główny koszt świadczenia usług opiekuńczych związany jest z wypłatą uposażeń opiekunom. W zakresie tej formy wsparcia nie ma kosztów pośrednich w postaci nakładów na wyposażenie stanowiska pracy, utrzymania lokalu itp. Główny koszt stanowią pensje pracowników. W tej materii można szukać oszczędności, zmniejszając pensje lub ograniczając liczbę godzin opieki. W przypadku firm częstą praktyką jest zatrudnianie pracowników na umowy cywilno-prawne. Pracownikom nie przysługują płatne urlopy czy też zwolnienia lekarskie. Wysokość ich uposażeń zależna jest od liczby wypracowanych godzin, a stawka godzinowa często jest na najniższym przewidzianym prawnie poziomie. Brak stabilności zawodowej nie sprzyja wstępowaniu do zawodu osób, które mają odpowiednie kwalifikacje.

$* * *$

Jeśli nie zostaną wprowadzone działania mające na celu przygotowanie instytucji pomocy społecznej do wyzwań, jakie wiążą się ze starzeniem się populacji i wzrostem zapotrzebowania na świadczenia opiekuńcze w formie środowiskowej i stacjonarnej, wzrastać będą deficyty w zakresie realizacji świadczeń. Wydłużą się kolejki osób oczekujących na miejsce w DPS, zmniejszy się dostępność do świadczeń realizowanych w formie środowiskowej. Ponadto należy mieć na uwadze, że koszty świadczenia 
usług opiekuńczych będą wzrastały i potrzebne jest opracowanie nowych mechanizmów finansowania opieki. Niezbędne wydaje się wprowadzenie ubezpieczenia pielęgnacyjnego, które pozwoliłoby na sfinansowanie choć części kosztów opieki długoterminowej nad niesamodzielnymi osobami starszymi. Obecnie dostępność do świadczeń w zakresie stacjonarnej opieki długoterminowej w wielu przypadkach zależna jest od zasobów finansowych poszczególnych gmin.

Aby zadbać o seniorów potrzebujących wsparcia, należy w pierwszej kolejności uwzględnić warunki pracy i płacy ich opiekunów. Jeśli nie zostaną podniesione ich pensje, za kilka lat problem braku opiekunów, pracowników socjalnych, pokojowych, terapeutów zajęciowych i pielęgniarek może uniemożliwić poprawne działanie instytucji pomocowych, zarówno ośrodków pomocy społecznej, jak i domów pomocy społecznej. Powinno zostać ustalone minimalne wynagrodzenie dla pracowników pomocy społecznej na poziomie kraju, które będzie powiązane ze średnim wynagrodzeniem w sektorze przedsiębiorstw.

Konieczne jest rozbudowywanie zasobów instytucjonalnych, które są niezbędne do zapewnienia seniorom wsparcia, należy zwrócić szczególną uwagę na: domy pomocy społecznej, dzienne domy pomocy społecznej, mieszkania chronione i wspomagane, kluby seniora (w tym profilowane, np. świetlice dla chorych na Alzheimera), wypożyczalnie sprzętu i akcesoriów niezbędnych do opieki itd. Warto również rozbudowywać sieć wsparcia udzielanego przez pracowników sektora pomocy społecznej, w tym w szczególności opiekunki środowiskowe i pracowników socjalnych.

Sektory pomocy społecznej i ochrony zdrowia powinny ściśle współpracować, mając na uwadze dobro i potrzeby niesamodzielnych osób starszych. Jedną z najpilniejszych potrzeb wydaje się możliwość kontraktowania usług pielęgniarskich przez domy pomocy społecznej z Narodowego Funduszu Zdrowia. Pielęgniarki są niezbędne w opiece stacjonarnej, jeśli nie podjęte zostaną działania mające na celu podniesienie atrakcyjności (głównie poprzez wzrost uposażeń) pracy pielęgniarek w domach pomocy społecznej, może doprowadzić to do sytuacji, że za 5 lat w niektórych placówkach nie będzie żadnej pielęgniarki. Problem jest szczególnie istotny w instytucjach oddalonych od dużych aglomeracji. Obecnie domy pomocy społecznej zlokalizowane na prowincji stanowią mało atrakcyjne miejsce pracy dla absolwentów kierunków pielęgniarskich. 


\section{Bibliografia}

Bakalarczyk, R. (2017). Kwestia opiekuńcza w agendzie polityki senioralnej w Polsce. Studia z Polityki Publicznej, 4(16): 82.

Giezek, M., Iwański, R. (2017). Mieszkania chronione i wspomagane dla osób starszych w ujęciu społeczno-ekonomicznym. Handel Wewnętrzny, 4(369), t. 1: 291.

Giezek, M., Iwański, R., Bażydło, M., Zabielska, P., Paszkiewicz, M., Karakiewicz-Krawczyk, K., Flaga-Gieruszyńska, K., Karakiewicz, B. (2018). Problem ponoszenia kosztów związanych ze starzeniem się społeczeństwa - analiza na przykładzie domów pomocy społecznej w gminie miejskiej Szczecin. Pomeranian J Life Sci, 64(4): 49-53.

GUS (2018). Rocznik demograficzny 2017. Warszawa: 6-8.

GUS (2018b). Informacja o sytuacji osób starszych na podstawie badań Głównego Urzędu Statystycznego. Warszawa: 6-8.

Iwański, R. (2017). Nowe oblicza starości z perspektywy dalszego starzenia się populacji. Studia Oeconomica Posnaniensia, 5(11): 113-128.

Iwański, R. (2018). Opieka długoterminowa nad osobami starszymi. Warszawa: CeDeWu.

Krzyszkowski, J. (2018). Deinstytucjonalizacja usług dla seniorów jako element polityki senioralnej. Problemy Polityki Społecznej, 42(3): 37.

NIK (2018). Usługi opiekuńcze świadczone osobom starszym w miejscu zamieszkania, Warszawa.

Szatur-Jaworska, B. (2015). Polityka senioralna w Polsce - analiza agendy. Problemy Polityki Społecznej. Studia i Dyskusje, 30(3): 72.

The 2018 Ageing Report Economic \& Budgetary Projections for the 28 EU Member States (2016-2070), Luxembourg: Publications Office of the European Union, 2018, https:// ec.europa.eu/info/publications/economic-and-financial-affairs-publications_en

\section{Akty prawne:}

Obwieszczenie Ministra Rodziny, Pracy i Polityki Społecznej z dnia 23 marca 2018 r. w sprawie ogłoszenia jednolitego tekstu rozporządzenia Ministra Pracy i Polityki Społecznej w sprawie domów pomocy społecznej, Dz. U. 2018, poz. 734.

Rozporządzenie Ministra Rodziny, Pracy i Polityki Społecznej z dnia 27 kwietnia 2018 r. w sprawie minimalnych standardów noclegowni, schronisk dla osób bezdomnych, schronisk dla osób bezdomnych z usługami opiekuńczymi i ogrzewalni, Dz. U. 2018, poz. 896.

Ustawa z dnia 12 marca 2004 r. o pomocy społecznej, Dz. U. 2004, nr 64, poz. 593. 